\title{
11. SITE 312: HAWAIIAN MAGNETIC LINEATIONS
}

\author{
The Shipboard Scientific Party ${ }^{1}$
}

After leaving Site 311 , we attempted to find a site on Mesozoic magnetic anomalies $\mathrm{M}-1$ or $\mathrm{M}-2$ where the airgun and $12-\mathrm{kHz}$ records would indicate that we could spud in the bottom-hole assembly, in order to carry out our principal objective of dating the sediment lying over basement at the young end of the Mesozoic magnetic reversal sequence. We surveyed southeast parallel to the anomalies, and then after crossing a fracture zone we jogged northeast to the offset of anomaly $\mathrm{M}-1$. Thence we continued southeast in the vicinity of the Vema-2405 track which showed an apparent gap in the heavy nearsurface seismic reflector. We did not see any such gap on our crossing, and so we doubled back, along anomaly M-2. We did discover a gap in the reflector at about $25^{\circ} 34.70^{\prime} \mathrm{N}, 178^{\circ} 08.00^{\prime} \mathrm{W}$ (Figures 1 and 2), and dropped a beacon at 0822 (local) on 29 September 1973 , in 5345 meters depth, for Site 312 .

However, after being unable to run in any of the drill string other than the bottom-hole assembly, because of the heavy swell and wind from a nearby storm, not enough time remained to drill and core to achieve our primary objective of dating basement, and then travel to Honolulu. After a little more than one day we abandoned the site without having reached the sea floor. A site number was assigned to account for the expenditure of the beacon and ship's time. We departed eastward (Figure 2).

'Roger L. Larson, Lamont-Doherty Geological Observatory, Palisades, New York (Co-chief scientist); Ralph Moberly, Hawaii Institute of Geophysics, Honolulu, Hawaii (Co-chief scientist); David Bukry, U.S. Geological Survey, La Jolla, California; Helen P. Foreman, Oberlin College, Oberlin, Ohio; James V. Gardner, Scripps Institution of Oceanography, La Jolla, California; John B. Keene, Scripps Institution of Oceanography, La Jolla, California; Yves Lancelot, Lamont-Doherty Geological Observatory, Palisades, New York; Hanspeter Luterbacher, Esso Production Research-European, Begles, France; Monte C. Marshall, U. S. Geological Survey, Menlo Park, California; Albert Matter, Universitat Bern, Bern, Switzerland.
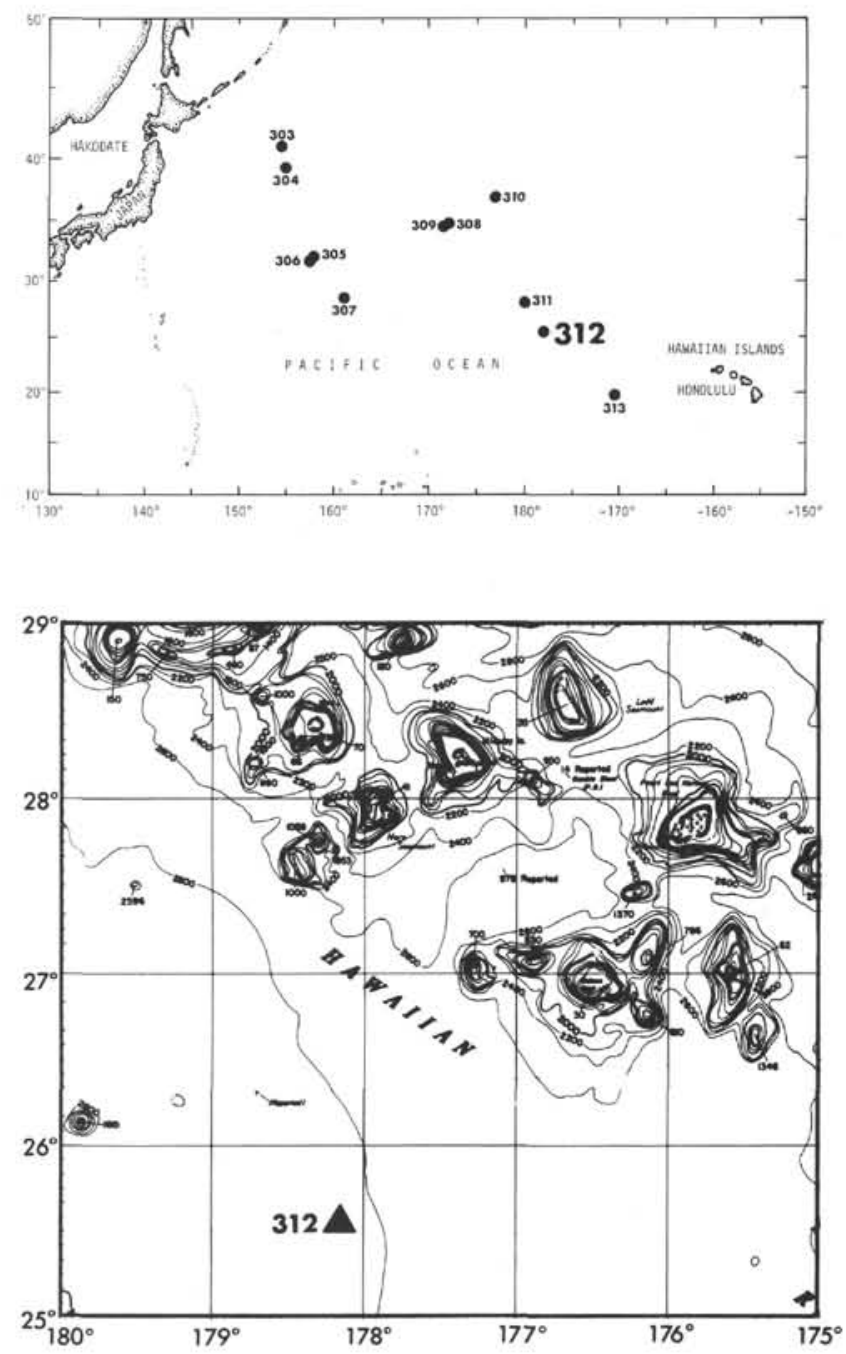

Figure 1. Bathymetry in the region of Site 312 (after Chase et al., 1971). Contour interval $200 \mathrm{fm}$ uncorrected.

\section{REFERENCE}

Chase, T. E., Menard, H. W., and Mammerickx, J., 1971. Topography of the North Pacific: Institute of Marine Resources, University of California, San Diego. 


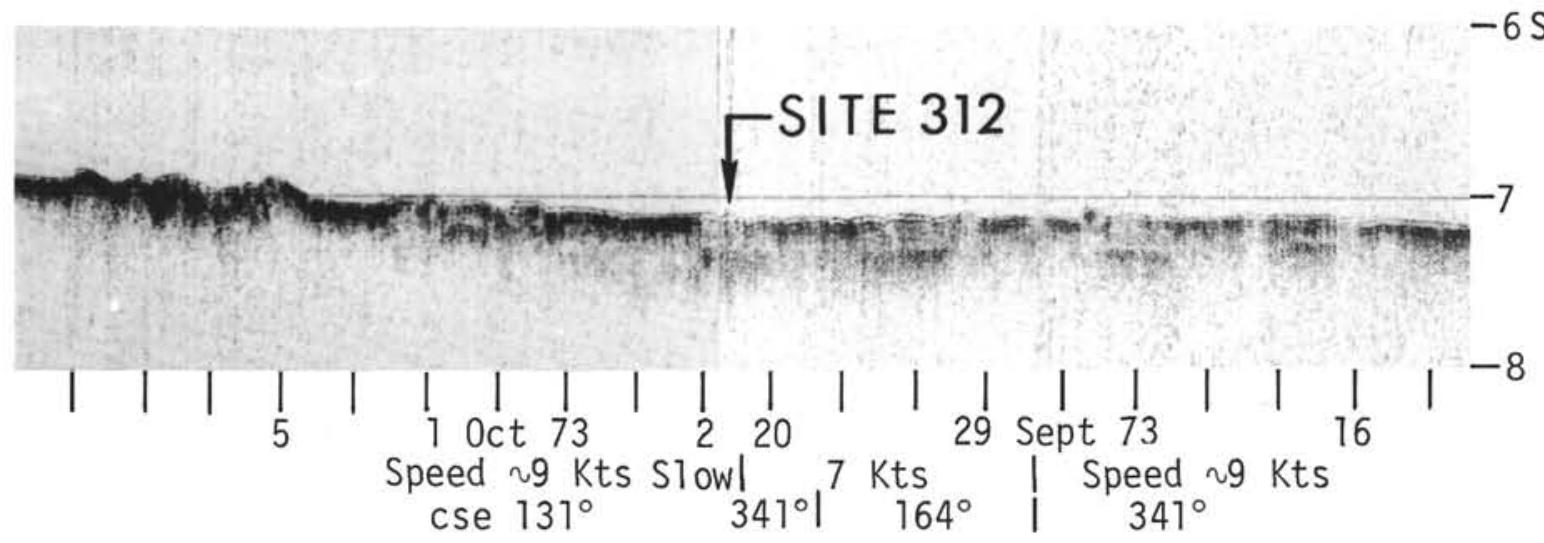

Figure 2. Seismic profiler sections approaching and leaving Site 312. 